Carmen Egea Jimenez Monsieur Vicente Rodriguez Rodriguez

\title{
Determinants of migration in the province of Jaén, Andalusia
}

In: Espace, populations, sociétés, 2002-1-2. Géographie et population. pp. 109-124.

Citer ce document / Cite this document :

Egea Jimenez Carmen, Rodriguez Rodriguez Vicente. Determinants of migration in the province of Jaén, Andalusia. In: Espace, populations, sociétés, 2002-1-2. Géographie et population. pp. 109-124.

http://www.persee.fr/web/revues/home/prescript/article/espos_0755-7809_2002_num_20_1_2023 


\section{Abstract}

Migratory movements have been a recurrent theme of study in the field of Population Geography. In Spain, attention has focused on emigration after the civil war; and on the more recent immigratory movement. The return movement has always been deemed less important, although it is very interesting due to the significance of the emigration to which it is associated.

More often than not, macroeconomic models have been used to explain the migratory phenomenon from the theoretical viewpoint, while a quantitative approach has been taken from the methodological viewpoint. Both have "forgotten" about emigrants themselves, and the personal circumstances that prompt them to emigrate and return. Therefore approaches that combine macro- and micro-aspects are required. In this respect, the methodology proposed is to use qualitative techniques to ascertain the migrants' life path, such as in-depth interviews, used in this case to analyse the life path of the retired emigrants of the province of Jaén, focusing in particular on their reasons for emigrating and for returning or not returning.

\section{Résumé}

Caractéristiques et facteurs déterminants des migrations et mouvements de retour en Andalousie. Le cas de la province de Jaén.

Les mouvements migratoires sont un thème d'étude récurent en géographie de la population. En Espagne les principaux centres d'intérêt sont l'émigration qui a suivi la guerre civile et les mouvements récents d'immigration. Les mouvements de retour ont toujours été considérés comme moins importants, même s'ils sont une partie intégrante de l'étude de l'émigration.

On a souvent utilisé des modèles macroéconomiques pour expliquer le phénomène migratoire sur le plan théorique, tandis qu'on utilisait des méthodes quantitatives sur le plan méthodologique. Ces deux approches ont négligé les migrants eux- mêmes et les circonstances ayant entraîné la décision d'émigrer ou de rentrer. Pour y remédier il est nécessaire de combiner macro- et micro-approches. La méthode préconisée dans cet article est d'utiliser des techniques qualitatives pour vérifier les trajectoires individuelles des migrants, comme les interviews en profondeur, utilisées dans ici pour reconstituer les trajectoires des émigrés retraités de la province de Jaén, en mettant plus particulièrement l'accent sur les motivations d'émigration et de retour ou de non-retour. 


\author{
Carmen EGEA JIMÉNEZ
}

Department of Human Geography

University of Granada

Facultad de Filosofia y Letras

Campus Univ. Cartuja s/n

18071 Granada

Spain

cegea@ugr.es
Vicente RODRIGUEZ RODRIGUEZ
Institute of Economics and Geography

Council for Scientific Research

Consejo Superior de Investigaciones Cientificas

Pinar 25

28006 Madrid

Spain

rodri@ieg.csic.es

\section{Determinants of migration in the province of Jaén, Andalusia}

Perhaps one of the subjects that has attracted most attention in Population Geography studies has been migratory movements and, in the case of Spain, this has focused on two of the main movements. One is emigration, in which a lot of Spanish people have traditionally been involved within Spain, or to overseas or European countries. Migrants were mainly young people who moved from rural areas to European countries and to the more developed provinces of Spain, during a fairy long period of time (from the Fifties to the mid-Seventies). The other is the immigration movement, in which Spain is acting now as the receiving country of young people from European, North African and Latin American countries. At present, this movement is attracting the attention of scientists from different fields of research, as demonstrated by the abundant bibliography, not forgetting its presence in the media.

Return movements, understood as migration to the place of origin by former emigrants, have always been deemed less important. However, any departure movement implies the possibility of a return. a phenomenon which, in the case of Spain and due to the importance of migration, is an aspect of great interest for scientific research. This phenomenon began to become noticed in the Seventies, when the world economic crisis encouraged many retired emigrants overseas, and even those who had migrated within Spain, to return to their place of origin. However, in practice the almost total lack of administrative mechanisms to facilitate that return, together with other personal and financial reasons, hindered that return.

Therefore this movement is never going to be as important as emigration was in its time, but it is becoming consolidated as an ongoing trend. The importance of this movement is to be seen in papers that describe and analyse the phenomenon from a general perspective in Spain (Garmendia, 1981; Pascual, 1983; Cazorla, 1989), or a regional perspective (Azcárate, 1988: Arroyo and Machado, 1989; IEA. 1993; Delgado and Ascanio, 1996; Gómez and Bel, 1999 ) or local point of view (Pascual and Cardelús, 1991-2; Egea, 2000). However, the study of the return movement is still 
subject to the tyranny of those who seek to focus on the number of young people affected and its territorial effects (Pascual, 1983; Azcárate, 1988; Gómez and Bel, 1999), on the theoretical relationship that can be established with the primitive current of emigrants (Pascual, 1993), on the official aid they receive, etc.

Most research into Spanish migration takes a quantitative approach, seeking to ascertain how many they are, where they are and what they are like from the structural demographic viewpoint, explaining and justifying its existence in macroeconomic models and global patterns of behaviour. Most times these approaches neglect other individual and/or family circumstances that might also be decisive factors in the decision to migrate, and that are harder to ascertain with a merely quantitative analysis.

Very broadly speaking, the models used to explain migratory movements have passed through a very well-defined time sequence. The modernisation model of the Sixties explains that countryside-city migration is perfectly justifiable in the transition from a traditional society to a modern one. Internal migration is a form of success on the road to progress (Eisenstadt, 1973). In the midSeventies, this model gave way to the dependency model which, "taking the world system as the unit of analysis and based on the Marxist theoretical and conceptual apparatus, regards the structural relations of exploitation as the cause of the development of migratory movements" (Wallerstein, 1974, cit. in Lacomba, 2001). These two models were left behind by a third approach, which in turn comprises elements from the two. This was the push and pull model, according to which migration is the manifestation of the migrant population's less favourable situation in their place of origin and the result of the poverty and backwardness of those issuing areas (Stark, 1991). At the same time, and from a sociological per- spective, researchers have focused on phenomenological approaches and on issues related to social conflict (Castillo, 1997).

None of these models have managed to explain why similar movements did not arise in countries with similar problems, "or why the places of origin for overseas migration tend to be concentrated in certain regions and not in others of the same issuing countries" (Portes and Böröcz, 1998, p. 45). Or, just as important if one goes into further detail, why some people decide to move and others do not when they face similar circumstances. Unquestionably, this issue can only be answered by combining world conditioning factors (economy, politics), personal and family circumstances, as the support or stimulus caused by prior migration, etc. (Malgesini, 1998).

The limited explanations afforded by these approaches and the desire to ascertain more about the "raison d'être" of migration has prompted research into this issue from other theoretical and methodological approaches, in an attempt to combine the more general conditioning factors (macro), with others that consider individuals and their micro context. Evidently, from the methodological perspective, these new proposals entail using qualitative research techniques to make it possible to attach as much importance "to structural (world, regional and local) contexts as to individual behaviour, the organisation of the family and social networks" (Wood, 1992, p. 38). Traditionally, researchers have used questionnaires and interviews to ascertain emigrants' opinions (Garmendía, 1981; Cazorla, 1989), yet without paying much attention to the emigrants' life courses (Cazorla, 1989).

The study of individual paths and the reasons that prompt emigrants to change residence is precisely one of the aspects least covered by return migration research. This paper endeavours to advance in this direction, and is firmly committed to the qualitative approach.

\section{OB.JECTIVES AND METHODOLOGY}

This paper aims precisely to combine the theoretical and methodological aspects within the new lines of research into the migratory phenomenon, defining types of 
reasons for emigrating and returning on the basis of the testimony of the people involved (emigrants). In methodological terms, this testimony has been obtained through indepth interviews, which have let us compare the prevailing circumstances that explained the decision to emigrate and the reasons that explained the decision to return or not return after spending time as emigrants. Such a decision, induced by a structural situation, is explained within a personal experience that is formed by a series of personal events. In the "in-depth interviews", the interviewees "weave" their memories, accompanied by different types of emotions, thereby also demonstrating how decisive a role certain situations played in choosing one option or another. Not forgetting that quite often interviewees turn to anecdotes to better explain their decision to move, or any other circumstance. Therefore, their life documentation offers far more opportunities to answer than, for example, the surveys system which almost always ask questions that have "limited answers", respondents are forced to "narrate" their lives in a restricted way, and there is no room for any spontaneity or emotion in the story, two factors that are very necessary both for telling and understanding the reason for certain decisions.

This methodology forms part of the biometric quantitative techniques. According to Pujadas (1992, p. 44), the biographic method is a combination of "the subjective testimony of an individual in the light of his life path, his experiences, of his private decision, and the expression of a life that is a reflection of an era, of social norms and of values that are essentially shared with the community to which the subject belongs". This method is based on personal documents as varied as autobiographies, personal diaries, letters, obituaries, photographs, life stories and tales, personal experiences and stories, oral stories and biographies.

Of this list of documents related to a person's life, we use the life stories, following the definition given by Santamarina $y$ Marinas (1994), for whom life stories are "the tales that are told with an intention to draw up and convey a personal or collective memory that refers to the lifestyles of a community in a given period of history". In this research, the individual life stories have been rebuilt through in-depth interview's that "allow the subjects to express themselves freely, to build their own, personal sense of existence, obtaining as much of the wealth of information that is lost in other quantitative techniques, with closed, pre-coded questions" (Ramírez Goicoechea, 1996). In short, the idea is to ask respondents about different subject to encourage them to talk about their own lives.

It is worth mentioning two further aspects about this type of analysis. First of all, it must be stressed that the number of people interviewed does not depend on the result of a statistical sample, because the snow ball sampling method is used (Mercadé, 1986). Interviewers start with a small list of respondents, or of other people who can give information about where to find respondents, so that one respondent leads to another. The number of interviews ends when the information given by one person does not contribute at all to all the information already obtained. In other words, it ends when the information reaches a saturation point, which consists of comparing each story to the next, in order to try to isolate any elements that coincide, and continue until any new story is unable to contribute any new structural element. It is a question of "building a single story from many different tales" (Pujadas, 1992, p. 55).

The contents of the interview cover all the subjects that might be related to the emigrant's life path, from their situation at the place of origin to that in the place of emigration or again in the place of origin, to the reasons for emigrating, their employment history, family history, adaptation-integration process at the place of emigration, and their ties between the place of emigration and the place of origin. With regard to the return, we have identified the approaches prior to the return, the decision to return or not, readapting situation, knowledge about the migratory experience of other friends and acquaintances, etc.

Therefore this study constitutes a small part of the information/documentation offered by each of the interviewees, but just as important because it compares the decision to emigrate and return, the start and the end of a path. 
Map 1. Municipalities where people were interviewed

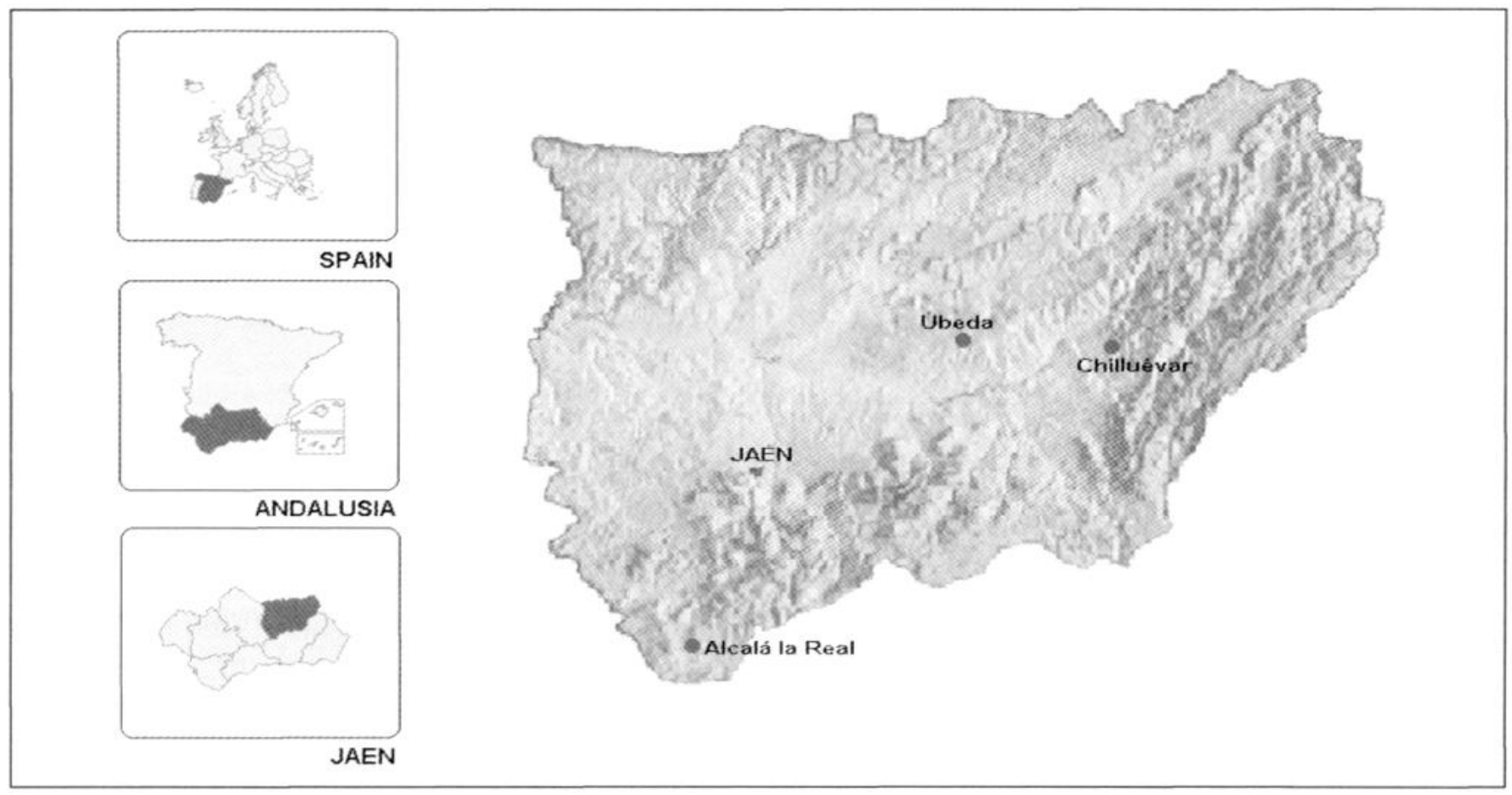

\section{2. (GENERAL CHARACTERISTICS OF THE RESPONDENTS}

This research analyses the life path of "returned and non-returned retired emigrants from the province of Jaén", through their reasons for emigrating and returning. The research focused on one of the provinces of Andalusia, namely Jaén (Map 1), which witnessed one of the highest levels of emigration from the Fifties until the Seventies: between 1964 and 1977 Jaén accounted for $4 \%$ of Spanish overseas emigrants, and almost $10 \%$ of the province's population emigrated (Garmendia, 1981). In the second half of the Seventies and in the Eighties, emigration dropped both in absolute and relative terms (Pujadas and García, 1995). In addition, this province has economic and social characteristics which, theoretically, could justify ongoing migration: it is eminently rural, and almost exclusively given over to agriculture, with olives being virtually the only crop grown; the land is divided into large estates that are farmed by labourers employed on a daily basis, giving rise to a cacique-type system with unfair working and employment conditions; and strong demographic pressure that is partially unsustainable due to the economic conditions and the way in which resources are distributed.
The emigrants who left from the Fifties until the first half of the Seventies, have spent and/or spend at least two decades as emigrants, in other words, most of their adult and working life. These people emigrated at a very specific point in time of the history of Spain, and now have retired. At this new stage of their life path, they arc most likcly to consider returning to their place of origin: at one point in their lives, they left home in order to look for work, but now that is no longer a conditioning factor for continuing to live in the place to which they emigrated. In fact some of these emigrants have now returned to their place of origin. Furthermore, the fact that they are more than 65 years old gives them the "life experience" from the place of origin to the place of destination.

In this research, return is deemed to mean the return to the place of origin, i.e., to the place that one left, which is the place of birth.

The respondents were contacted through Associations of Emigrants located outside Andalusia and managers of Old People's Homes. People of different origins (place of birth/return) and destination areas were sought in order to ascertain whether the 
reasons for emigrating differ from one place of origin to another, and the motivations for returning (or non returning) differ according to the places where they stayed as migrants. A total of 28 people from three municipalities of the province of Jaén were interviewed (Map 1):

- A mountain village (Chilluévar, in east Jaen), a small village that is hard to reach.

- A farming village, located in the southern mountain range (Alcalá La Real, in southwest Jaen).

- A small town located in the middle of the province, with a strong services sector (Úbeda).

The 28 respondents were 16 emigrants who have not returned and 12 who have, with the following general profiles: married men, single men, and widows. Almost all of the bachelors and widows are returned emigrants, but married people are the more usual profile. Some of them are related to one another (brothers, sisters or cousins), have migrated to the same or different places, or have taken the same decision to return to their place of origin, making it possible to compare whether people from the same family unit are driven by the same reasons.

Eighteen of these people are less than 75 years old, and the rest are older, but nobody is more than 80 years old. When they left their place of origin, most of them were already old enough to work, and were 18 years old or older (only 5 of them were younger). Some were more than or nearly 40 years old and were the last to leave, in the first half of the Seventies, just when the international recession led many companies to close and limited the conditions for the creation of employment. Those who emi- grated in the Fifties did so during the hungry years in Spain, when economic and social conditions were at their harshest, above all in the countryside, while those who emigrated in the Sixties did so at the height of Spain's development period, when heavy investments were made in the industrial sector in the Basque Country, Catalonia and Madrid. Therefore all the respondents except for three spent more than 20 years as emigrants and, significantly, twelve of the respondents have lived away from their place of origin for more than 40 years. Almost all of these people form part of the non-returned group, because most of those who have returned (twelve) did so before they were 70 years old, upon retiring (almost always early, at 62 or 63 ); they returned home in the Nineties and have been living in their place of origin between two and fourteen years (only one respondent has been living at his place of origin quite longer: twenty-six years, in this case a respondent who emigrated alone several years in a row).

As for the family history, an important element when taking the decision to emigrate and return, eleven respondents emigrated from their original family (i.c., formed by parents, brothers and sisters), and formed and consolidated their own family (spouse, two or more children and grandchildren) during their emigration. These belong to the non-returned group. The remaining seventeen emigrated with their own family with the children at school age but also old enough to work (some emigrated with their parents with the sole idea of working at that time or of working as soon as they were old enough). This family didn't grow with other sons, but with grandchildren some years late.

\section{REASONS FOR MIGRATING AND RETURNING AND LIFE COURSES}

Despite sharing fairly similar backgrounds, the reasons that made people emigrate and make later the decision to return or not return are affected by a wide variety of situations (Table $I$ ). The reasons affecting the three types of movement (migration, return and non-return) have been arranged in two major groups, depending on whether the decision to emigrate is prompted by an objective situation or of a subjective situation:

The objective reasons are caused by circumstances that are created in relation to the national and province economic. social and political situation, structural issues; and 
even the very environment in which the people live and work.

The subjective reasons are related more directly to the personal circumstances of each individual: need or desire to better oneself, family implications, previous cases of relatives and/or acquaintances who have emigrated, means to change one's place of residence, personal desire for change.

Depending on whether these objective and subjective reasons emerge at the place of origin or the place of destination and type of movement, the place of origin will act as a place that pushes the former emigrant or pulls the return migrant. The reasons could be classified in :

\section{Reasons for Emigrating}

In this case, it is evident that the reasons that drive the individuals from the place of origin are objective, because they are related to the country's economic, social and political situation (Table 1).

\section{REASONS FOR EMIGRATING}

\begin{tabular}{ccc}
\hline $\begin{array}{c}\text { Objective economic and social } \\
\text { reasons for being pushed from } \\
\text { the place of origin }\end{array}$ & $\begin{array}{c}\text { Expectations at the place of } \\
\text { destination as subjective } \\
\text { reason of attraction }\end{array}$ & $\begin{array}{c}\text { Role of the family at } \\
\text { destination and origin, as seen } \\
\text { by the individual }\end{array}$ \\
\hline
\end{tabular}

\subsection{Economic situation}

a) Economic hardship:

Debts.

Inheritance system.

Limited viability of the

family business.

Lack of own property.

b) Employment problems for the

head of the household and children

c) Conditions of employment:

Harsh.

Badly paid.

\subsection{Social situation}

(precariousness)

1. Social mobility:

a) Improve/raise the level of education.

b) Secure employment expectations (father and children)

c) Social and economic improvement expectations (the whole family).

d) Perform a qualified profession
1. Family support (relatives, friends, acquaintances):

a) "Call" effect

Relatives who have emigrated.

Information from friends who have emigrated.

Sending of contracts.

b) Involvement of one's "own"

family:

Reuniting the family.

Solve economic problems.

Solve health problems.

Support children's education.

a) Problems to bring up children.

b) Lack of basic commodities (hunger).

c) Lack of social mobility expectations.

d) Unfair social situation (caciquism).

3.3 Political situation.

Military service

Consequences of Civil War

The place of destination becomes an attraction, full of each individual's own subjective considerations. First, and even if the individual has never been to the place before, it offers plenty of prospects of finding a job and improving one's social and economic status both in the present and future. Second, the individual is supported by relatives, friends or acquaintances who have already migrated, who know the place and what it offers, and who encourage the individual to emigrate, and who reinforce it by setting themselves as examples of social and economic progress. He is also supported by the members of the individual's own family. who are directly involved in the agreement 
to depart in order to stay or be together (family regrouping), solve common problems related to the household economy, the health of one of its members, etc.

\section{Reasons for Returning.}

The objective reasons behind the decision to return are to be found in the place of destination, which now acts as the push factor. These reasons include reaching retirement age, as the decisive event that prompts many people to say to themselves mission accomplished and so consider returning home for good; and also all the circumstances that mean that the residential situation is not entirely satisfactory (climate-related health problems, housing bad quality, not knowing the language, a retirement pension that is too small to maintain a higher standard of living than in one's home town) (Table 2).

\begin{tabular}{|c|c|c|}
\hline \multicolumn{3}{|c|}{ REASONS FOR RETURNING } \\
\hline $\begin{array}{l}\text { Objective reasons } \\
\text { for leaving the place } \\
\text { of destination }\end{array}$ & $\begin{array}{l}\text { Role of the family } \\
\text { at destination and origin, } \\
\text { as stated by the individual }\end{array}$ & $\begin{array}{l}\text { Subjective ties } \\
\text { to the place } \\
\text { of origin }\end{array}$ \\
\hline $\begin{array}{l}\text { 1. Social and job situation: } \\
\text { a) Reaching retirement. } \\
\text { 2. Problems at the emigrant's } \\
\text { place of destination: } \\
\text { a) Climate-related health } \\
\text { problems. } \\
\text { b) Rundown housing. } \\
\text { c) Lack of knowledge of the } \\
\text { language. } \\
\text { d) Fall in purchasing power } \\
\text { upon retirement. }\end{array}$ & $\begin{array}{l}\text { 1. Family support: } \\
\text { a) Involvement of one's "own" } \\
\text { family: } \\
\text { Support of children and } \\
\text { spouse. } \\
\text { Support to older relatives. } \\
\text { Reuniting the family. } \\
\text { Non-involvement of children } \\
\text { and grandchildren. } \\
\text { b) Maintaining family ties: } \\
\text { Wish to be close to relatives }\end{array}$ & $\begin{array}{l}\text { 1. Keeping in touch: } \\
\text { a) Frequent visits. } \\
\text { b) Property investment. } \\
\text { c) Maintaining property. } \\
\text { d) Keeping positive memories } \\
\text { (nostalgia, yearning). }\end{array}$ \\
\hline
\end{tabular}

On these occasions, the family is also present in the decision to return, being the reasons related to this decision subjective, and they mean that the municipality of origin acts as a pull factor. Once again, the members of the family are involved in the decision to return, either supporting or making the decision, either in an attempt to reunite the family, or in order to help relatives with health problems. In this case, it is not essential for all the members of the family to return. Furthermore, the decision to return is reinforced by the ties maintained with the place of origin during the emigratory period because the emigrant has kept in touch with non-emigrated relatives (parents, brothers and sisters, children), for example, through frequent visits (holidays). These ties have prompted many of them to invest part of their income in maintaining tangible assets (a house or land), or in buying them for when they return. In addition, quite a lot of people have felt a certain nostalgia that has made them think, sometimes permanently, about returning.

\section{Reasons for not returning.}

These act as the negative side of the reasons for returning explained above and all are subjective, because there are no structural circumstances to prevent the individuals from returning, if they considered doing so, even being systems of aids to help them. Actually, very few people consider returning (shall I return or stay?), and even consider the idea unexpectedly or out of the blue during the interview (Table 3 ). 
REASONS FOR NOT RETURNING;

Reasons related to subjective perception of the place of origin
Reasons related to the role of the family at the place of destination, as subjective statement
Subjective reasons related to expectations/conditions to return
1. Breaking of ties:

a) No/infrequent visits to village.

b) Lack of own property.

c) Lack of relatives, friends, acquaintances.

2. Remembering negative reasons for emigrating.

3. Loss of quality of life:

a) Poor health services.

4. Unlikely to adapt. 1.b) Involvement of one's "own" family:

a) No support from spouse.

b) Family responsibilities (looking after grandchildren)

c) Security from children as support during illness.

2. Keeping in touch with relatives:

a) Re-uniting the family.

b) Having more friends.
1. Family support:

a) Children marry in the village.

b) Children employed in the village.

2.Conditions:

a) Younger age.

b) Better state of health.

c) More purchasing power.

d) Different marital status.
In these cases, the place of origin acts yet as a push factor, because they have no reasons to return to a place that they have visited very seldom, and where they have no property or very few relatives or friends. Furthermore, their longing to return is outweighed by the intense and negative memory of the reasons that prompted them to emigrate some years before. They are not very happy with the quality of the health services in their place of origin, this opinion being expressed by individuals who emigrated from the mountain municipality of Chilluévar, who feel they might find it very hard to adapt after such a long time.

In this case, the family also plays an almost decisive role. The family is at the emigrant's place of destination; some of its members really block this desire (mainly, spouse); they feel responsible for looking after their grandchildren; and they look upon their children as a source of support for when they are ill. Furthermore, the strongest family ties and bonds of friendship are to be found in the place of destination.

There are very few people who, even if they have decided not to return, toy or "fantasise" with the idea of returning, and once again these expectations are tied to the family: because a son or daughter might emigrate, either because he or she is getting married or has a job there. Sometimes they mention personal conditions, which are merely limitations: they are younger, healthier, have more purchasing power to make the change, or a different marital status, so the decision does not depend on anyone else.

In short, the following models of behaviour can be established in line with the type of movement:

\section{Reasons for emigrating:}

Economic and social reasons for being pushed from the place of origin
Expectations at

$+$ the place of destination
Role of the family at origin and destination

\section{Reasons for returning:}

Reasons for rejecting the place of destination
Role of the family at destination and origin
$+$

Ties to the place of origin 
4. Reasons for not returning:

$$
\begin{gathered}
\text { Perception of the place } \\
\text { of origin }
\end{gathered}
$$

Evidently, not all these reasons are always to be found in the same individual path, and when several of them are, they do not always matter as much to one person as to another. For example, while one reason might trigger some people to migrate or return, for others it might be just another factor. The same does not apply to the cases of non-return, where the importance of the family is almost the only or the main reason, such that the testimonies seem to reach saturation point very quickly. Nevertheless, the major or minor differences between each life story make it a unique case.

\section{CASE STUDIES}

By way of example, there follows a description of the reasons given for emigrating and for returning or not returning of some of the life courses analysed. The example consists of four cases of return: one to Chilluévar, two to Alcalá La Real and one to Úbeda; and two people who have not returned to Chilluévar.

Case Study 1. Return to Chilluévar

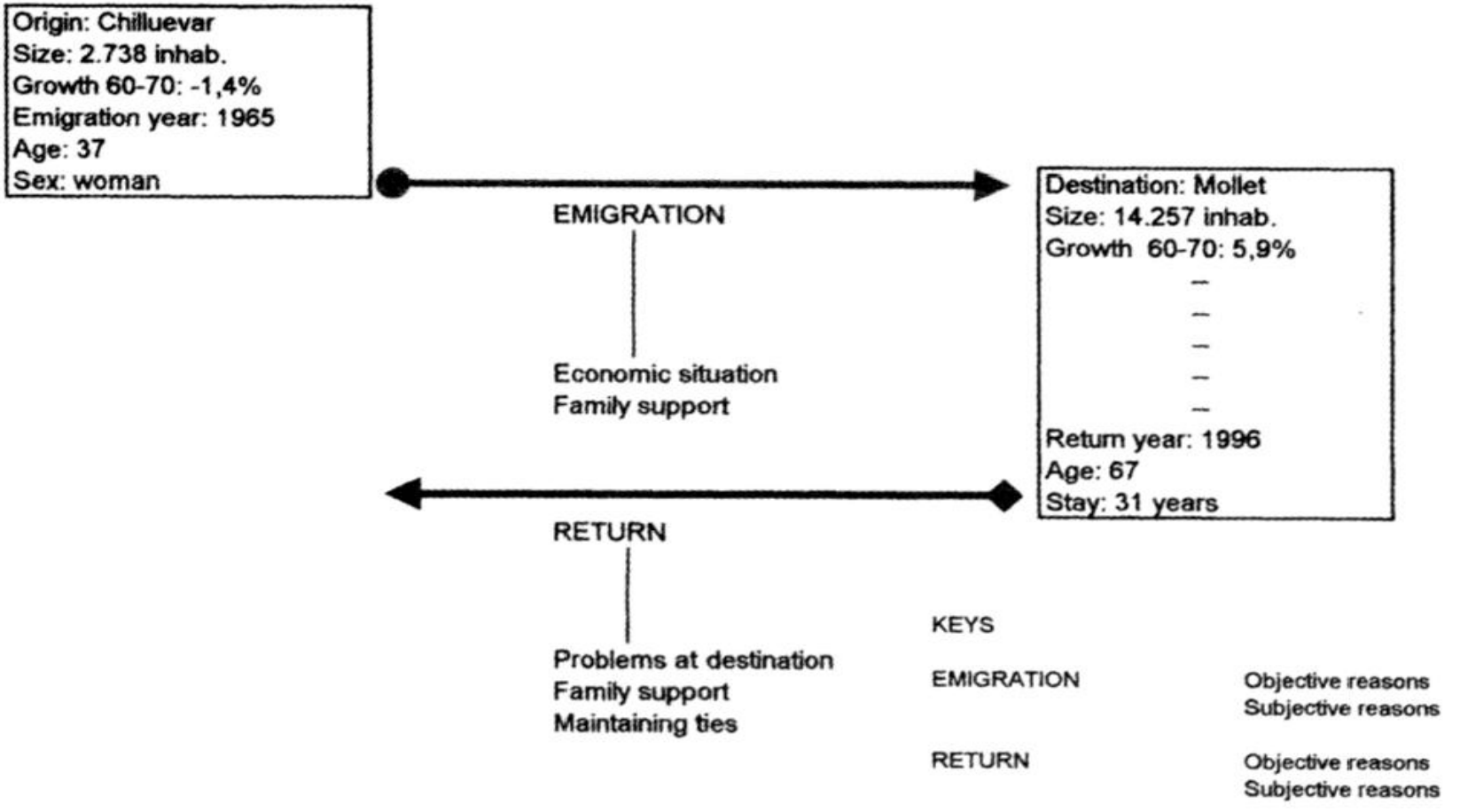

Case 1: this case involves the "return to Chilluevar" of a widow with five children. She emigrated at the age of 37 , with her husband. who was quite older than her (47) and had already emigrated on previous occasions to towns in the Pyrenees and in
Tarragona. Then, in approximately 1962, he found a steady job for himself and his elder son, who had gone with him, in Mollet (Barcelona). The rest of the family (spouse and four more children) joined the husband two years later, when he had a house. 
The main reason for emigrating was simply that there were no jobs in Chilluévar and he found it hard to support his family. He was only assured of a job during the olive harvest. Emigrating ensured a job both in the present and future for the head of the household and the children (three of them were still of school age). The first few years were not easy, if one takes into account that her husband suffered an accident at the work place when he was 50 years old and had to retire early, and the same happened to one of her children at the age of 15 .

The woman began to think about returning one year after her husband died, when she was 67 , and this was prompted by a series of circumstances: where they had emigrated, she would have to live either in a house that was too big for her alone, with 31 years of memories, or else live with one of her children; and the climate had never been too good for her health. At the place of origin. she had relatives in Chillúevar (where almost all her brothers and sisters live), with whom she has never lost touch, by visiting them frequently; and an unmarried son who has been living there for several years and has renovated a house for her. The rest of her children, and also her grandchildren, live in Barcelona, and she knows that she will miss them, but she is happy with the decision she has taken.

Case Study 2. Return to Alcalá La Real

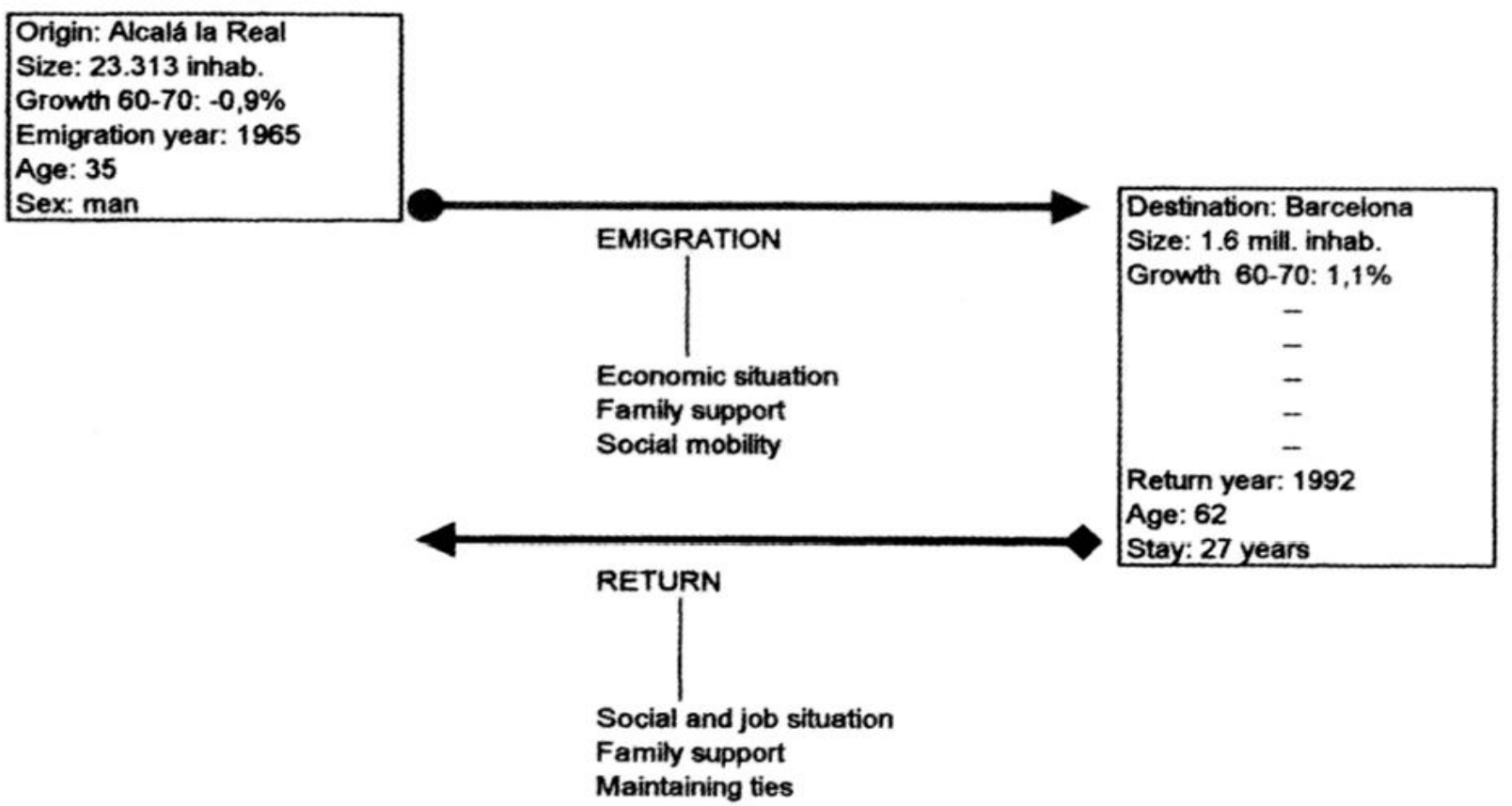

KEYS

EMIGRATION Objective reasons

Subjective reasons

RETURN

Case 2: this case involves the "return to Alcalá La Real" of a married man without any children. The first and only time that the man left the village was when he was 35 years old, in 1965, for Barcelona. He never imagined that he would live there so long, 29 years altogether, because he said that he was only going "to spend a few months at a relative's".

It was the inheritance system at origin that made him curious to travel to Barcelona and look for a job there. His father shared out his land among his children (seven) and he went from being a landowner to a day labourer. 
because the land he had inherited was not enough to make a living He did not like the new situation at all, because it meant he had to depend on other people wanting to give him a job. He went to Barcelona alone and, a few years later got married to a woman who had moved there from the Aragon region.

He retired early at the age of 62 in 1992, bringing forward the moment of the return, which is when he started thinking about buying a house in the village. He had no trouble leaving Barcelona, because he did not have any children and did not have to carry on working (almost certainly that is what he always thought). Furthermore, his wife supported the decision to migrate South and not to her place of origin. He has never lost touch with his village, where all his brothers and sisters live, and whom he has visited on holiday every year, accompanied by his wife and mother-in-law, who have become attached to the village. His sister, who emigrated to Switzerland in 196.5, returned a few years before he did, in 1985. She followed a different path, mainly because her reasons for returning almost exclusively mainly financial ones. Another brother still lives in France.

Case Study 3. Return to Alcala La Real

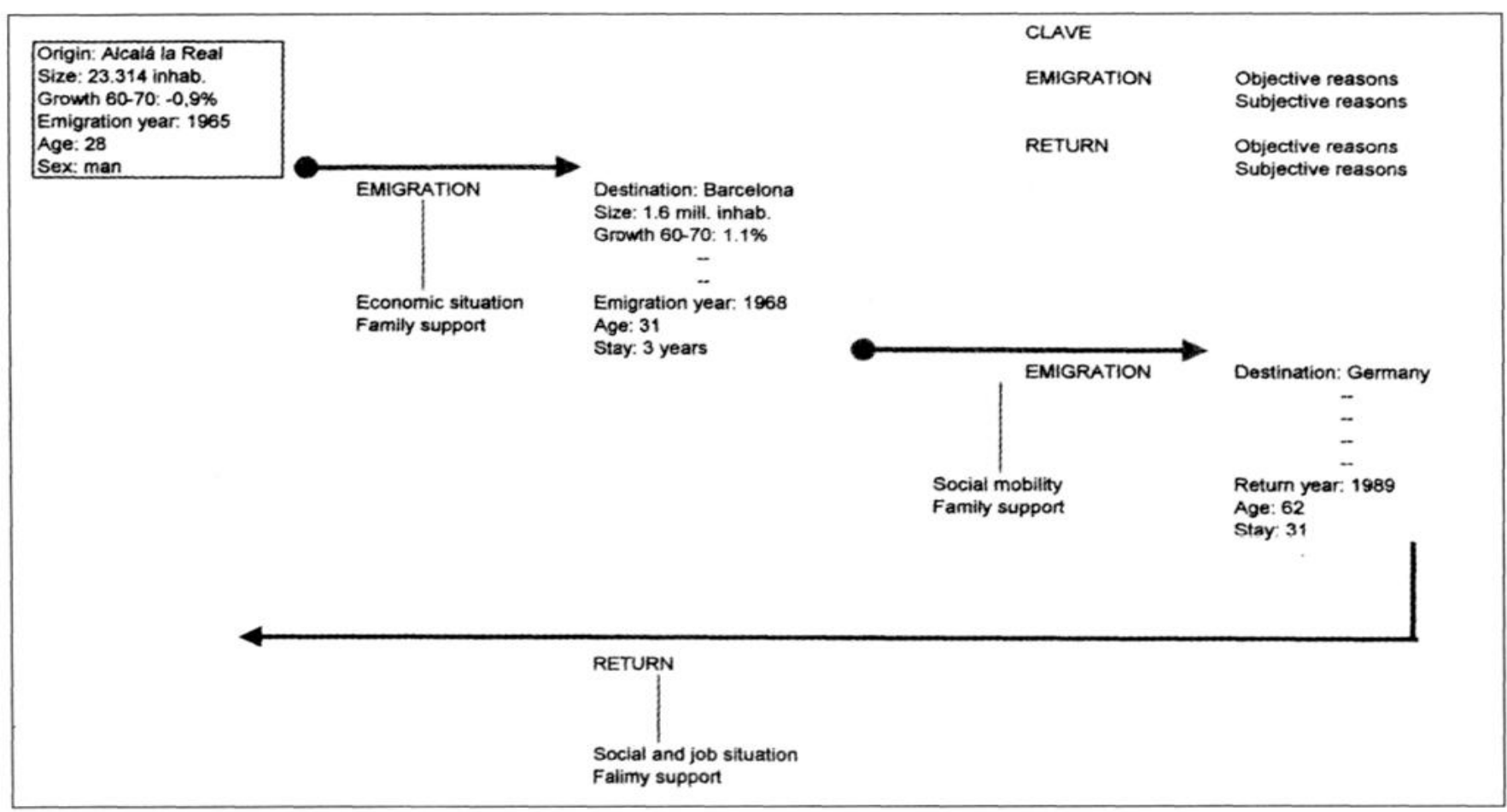

Case 3: return to Alcalá La Real of a bachelor. The man first migrated to the municipalities adjoining Alcalá La Real, with his family (parents and nine brothers and sisters), looking for somewhere to work as bakers. One by one, his brothers and sisters emigrated elsewhere as they saw little future in the bakery, and in the end it was the fact that he was 28 years old and still single that prompted him to try to find work outside the province of Jaén. In 1965 he emigrated to Barcelona, where one of his sisters lived. He spent 3 years living with her and working as a haulage contractor for a company. Another brother who had emigrated to Germany told him that he might be able to get a job at a bakery in another city in that country. So he moved to Germany and lived there from 1968 until he retired early at 62, in 1991.

He returned that same year. He did not think about it much: he did not have any family of his own at the place of destination (apart from a brother, nephews and nieces), or his own house, or "anything to do". Furthermore, his mother still lived in the village, so he would be able to look after her. His relatives in Germany are still urging him to emigrate again and live with them. 


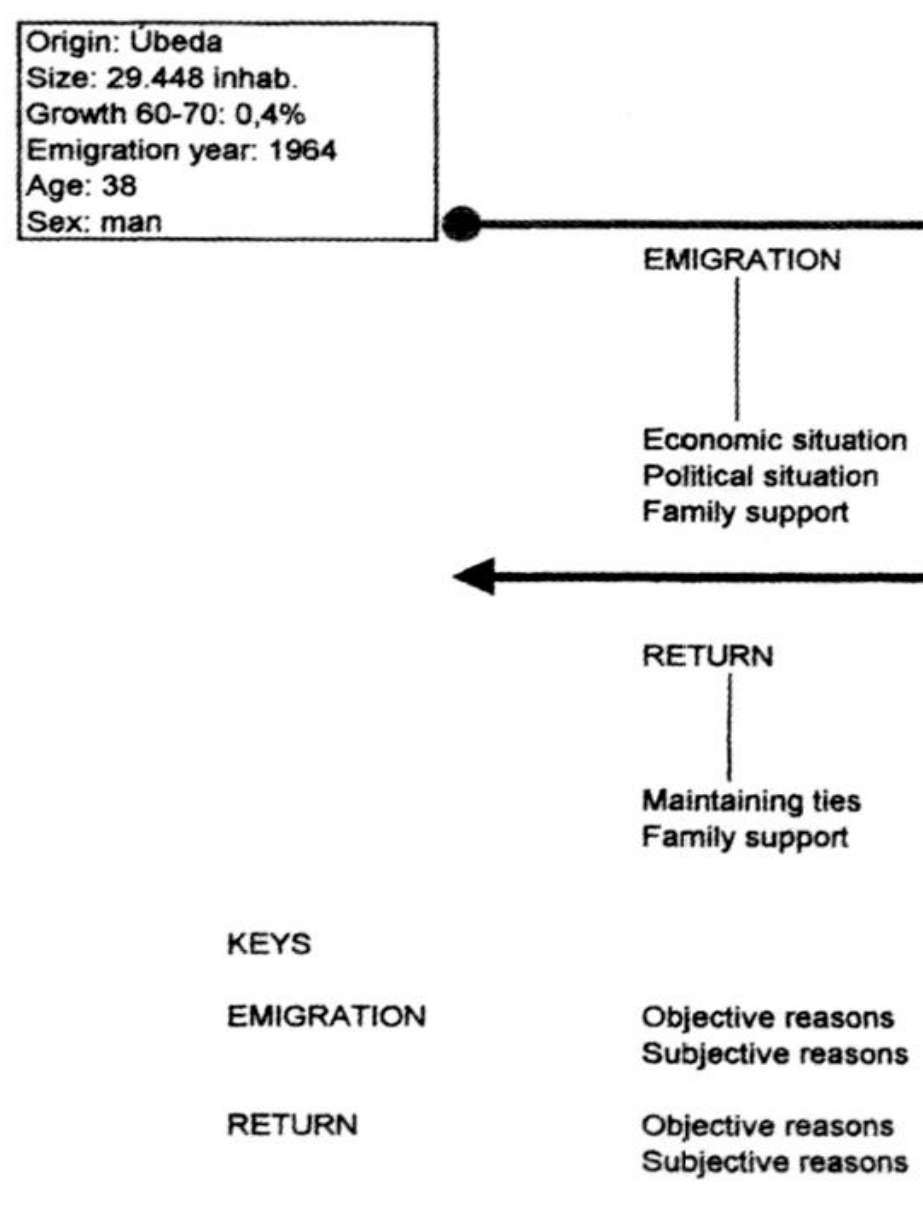

Case 4: "return to Úbeda" of a married man with two children. The man only migrated once, to Madrid in 1964, but in this case accompanied by his wife and two children. His reason for migrating was that he had been a cattle farmer, but had been ruined when all his animals started dying. He replaced them and tried to cure them, but ran up huge bills that he was unable to pay. Although this was what triggered his decision to migrate, another factor was the situation his family suffered during and after the Civil War. One of the reasons for moving to Madrid was that they had friends there who encouraged and helped them when they arrived (they spent a few months living in the house of some acquaintances).

After 24 years in Madrid, he returned in 1988 , at the age of 63 , when he retired. This return has been rather by chance. prompted by his elder son. who has a degree in Geography and History and is carrying out research on the City of Úbeda. which is where he met his wife. His younger son then followed in his brother's footsteps. So the parents have merely followed them as soon as they could, when the man retired. Apart from the "pull" effect of their children, they have always remained in touch with Úbeda where both the man' and his wife's family live, and where they have spent many holidays. A few years ago one of his first cousins returned to Ubeda at the age of 78, after having spent fifty years in Buenos Aires. His cousin's reasons for returning were almost exclusively political.

Case 5: this involves the "non-return to Chilluévar" of a married man with three children, one of who was born abroad. Unlike the others, apart from short stays in villages in the Pyrenees and Germany, the man and his family have spent 45 years as emigrants in two different places: first in Vall d'Uxó (Castellón), where they spent 14 years, and then in Parets del Vallés (Barcelona), where they have now lived for 31 years. 
Case Study 5. Non return. Man from Chilluévar

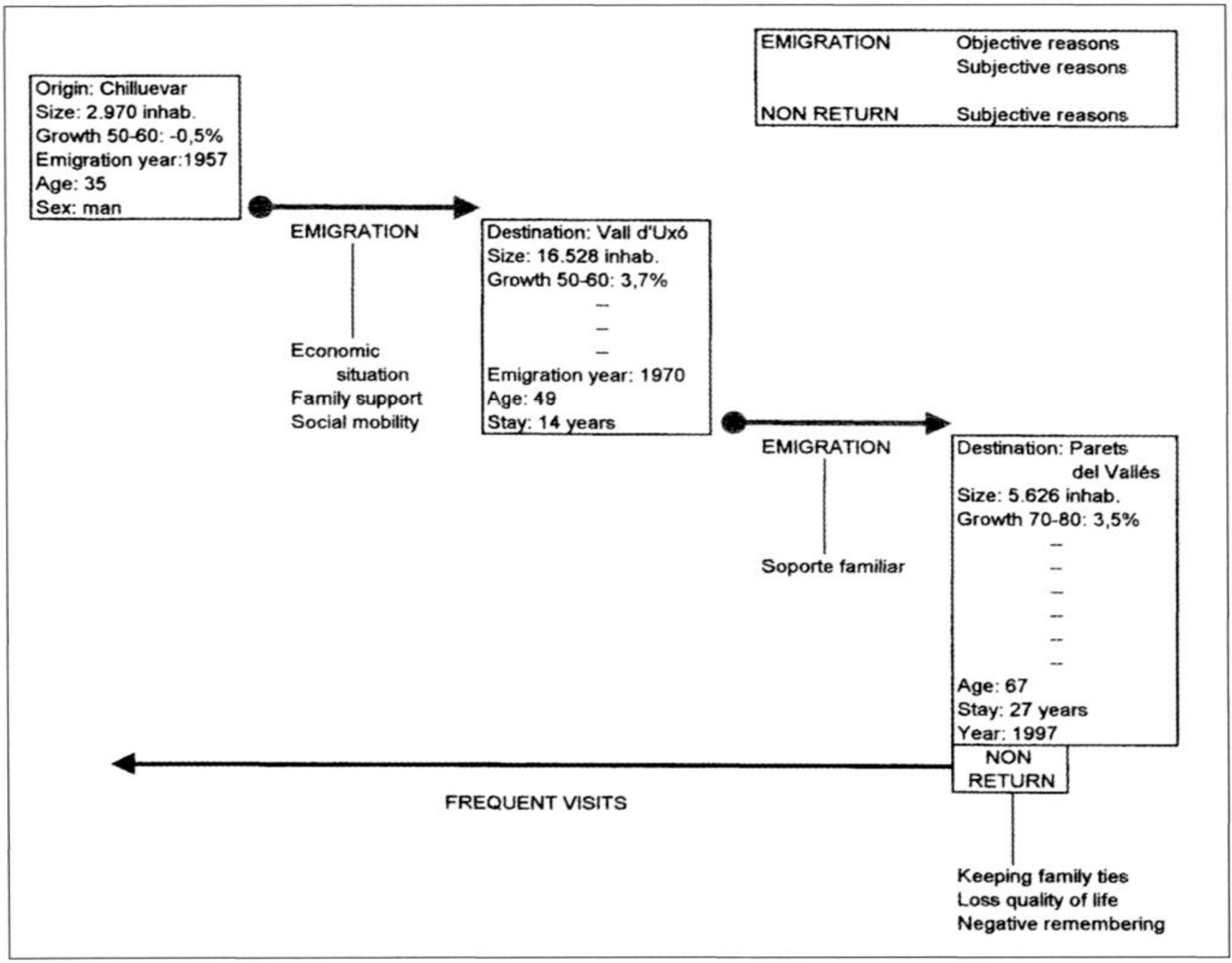

The reasons for emigrating had to do with: work (it was scarce, badly paid and harsh); it was a way of keeping the whole family together, instead of the man having to spend six months a year away from home; the prospects of a better future for his children; and a means of escaping the unfair social system that reigned in the village. The reason for moving from Vall d'Uxó to Parets del Vallés (second migratory step) was that a relative found a job in a factory for his elder son.

Despite missing life in the village (family, friends, festivals) and visiting it frequently, they have never thought about returning. If they moved again to return, it would be to Vall d'Uxó, where they have a house and his wife's brothers and sisters live; but, above all, his reasons for not returning and for staying in Parets del Vallés, are related to his desire to be close to his children and grandchildren. An added factor is that he has to undergo regular medical check-ups as a result of an industrial accident he had when he was 59 years old. Sometimes, when he remembers the reasons why he left the village for good, his opinion of the village is negative, although at other times he feels nostalgic and misses it.

Case 6: This man had been working at the Chamber of Agriculture in Chilluévar ever since he was 12 years old, where he acquired basic typing and shorthand skills. He had to do his military service and the fact that he could do it in Madrid meant a chance to improve and learn more clerical skills, as well as the chance to act as the "advance party", so that his parents and seven brothers and sisters could emigrate later as well, and enjoy a better future (all of them were farm labourers). He left for Madrid in 1952, at the age of 18 , and his parents, brothers and sisters fol- 


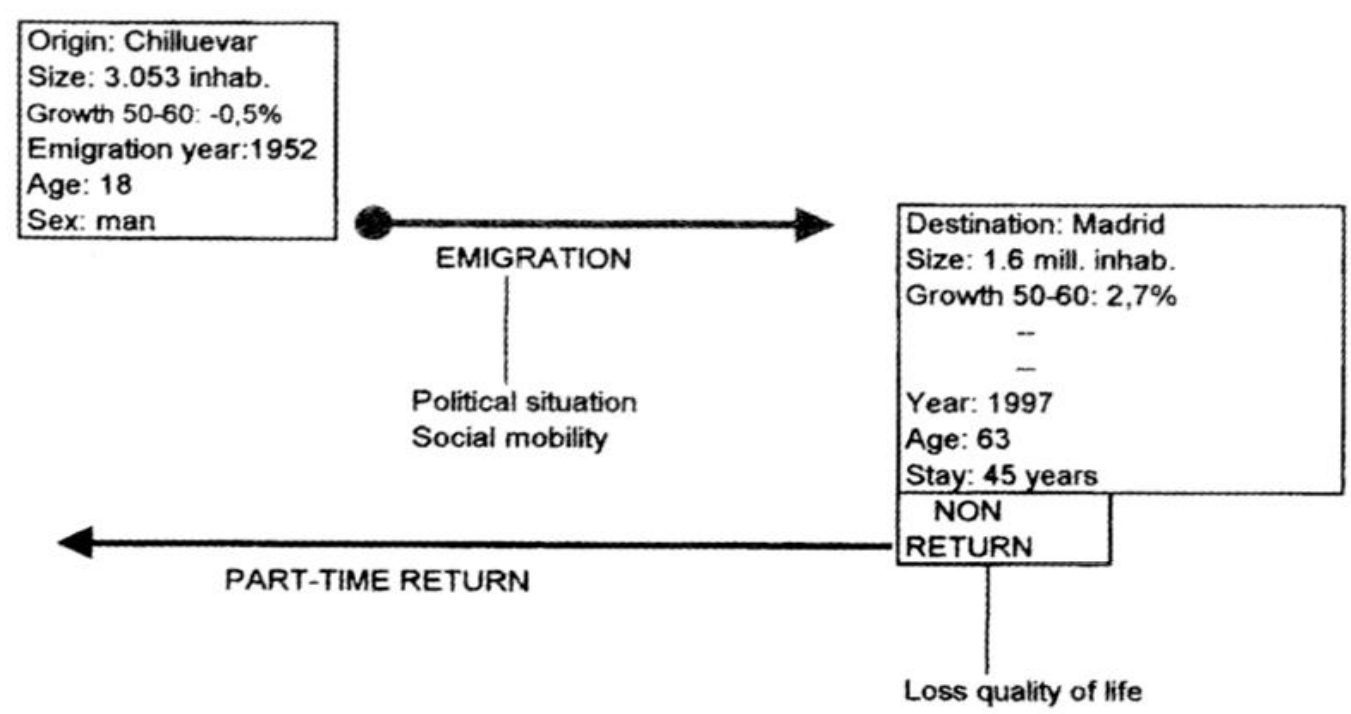

lowed him a few years later. In 1960 he married a woman from Chilluévar with whom he has had three children. Ever since he emigrated, almost fifty years ago, both he, his wife and children, have always gone back to the village on holidays, whenever they have had the chance, because they have relatives, friends and a house there.

Recently, and due to his mother-in-law's old age, they spend most of the winter in the vil- lage, so one might say that they are halfway between emigrants and returnees. However, they have never thought about returning: in Madrid they have fulfilled some of his dreams, namely to have a house in the country. They "return part-time" whenever they feel like it. Nor are their children a problem, especially because now they are grown-up and two of them no longer live with them.

\section{CONCLUSIONS}

The study shows that emigration is a complex phenomenon in terms of the reasons that prompt it, and that analyses based on general approaches, in which the importance of numbers and structural aspects take priority, are insufficient.

This complexity can only be ascertained through an in-depth analysis of the life courses of the people involved in this phenomenon, i.e. the emigrants. From the methodological viewpoint, we consider that, to ascertain that path, an in-depth interview provides much more information than a simple questionnaire. Although many of the answers sought can be obtained with closed questions, many other testimonies arise during the conversation with the respondent, who remembers more. the longer the interview lasts. There are also testimonies and experiences that cannot be expressed with the answers to the questionnaire.

Although each life path is unique, we must find a point, where, without losing sight of the exception of each case, we can establish types of reasons, as we have intended. This shows that the reasons that make people move are often subjective, and a large majority are related to the family (this being deemed to include direct relatives, friends and acquaintances).

The family is present in all the movements analysed (migration, return, non-return), sometimes fostering the movement, or hindering it at others, although its presence, as a factor that governs the decision to move is not always as important, nor does is it expressed in the same way. 
Nevertheless, and in relation to family ties, it does seem that having formed part of a family network plays a fundamental role in making the decision to emigrate, with emigration being related to better prospects of mobility for the children or brothers and sisters; however, when it comes to returning, the closest relatives, children and grandchildren, do not always justify the decision to return.

Likewise, the research shows that the decision to emigrate and return or not is less conditional upon the place of origin, as the usual criterion considered when selecting interviewees. Emigration in the province of Jaén took place both from the countryside and the urban areas, because the population characteristics of neither one nor the other necessarily offered any opportunity for social, economic, and personal progress or betterment, and instead became places that expelled their population. Meanwhile, the return very often represents the chance to finally feel to "return home", regardless of whether or not now it is better connected, has better social and health services, etc. However, these same accessibility and amenity factors can be a reason for nonreturn, although sometimes there is a lack of a real perspective of the way in which the province of Jaén has changed, in general, over the last few decades, with interviewees tending to remember the situation that existed when they emigrated a few decades ago.

The saturation of the information obtained seems to come with the reasons for not returning, but it must be taken into account that the sixteen emigrants who have not returned all come from the same village, Chilluévar. However, the respondents have not given the same reasons for leaving, nor for returning, not even when we analyse the paths of people who are related to one another and/or live in the same place. All this without taking into account other aspects not covered at this time such as work and family circumstances, the adaptationintegration process, etc.

Finally, it would be impossible to interview everyone who has emigrated, either in the place of emigration or the place of return, but is seems evident that the twenty-eight respondents have opened a wide range of possibilities that show, as we said at the beginning, that migration is a complex phenomenon, in which the fundamental elements are personal decisions and all the associated life circumstances.

\section{REFERENCES}

ALVAREZ SILVAR G. (1997), "Estado actual de la investigación sobre el retorno", in A. Irquierdo y (i. Alvare\%. Políticas de retorno de emigrame's. La Coruña. Universidad Internacional de La Coruña. $300 \mathrm{p}$.

ARROYO LOPEZ E., MACHADO SANTIAGO R. (1989), Jaén: retorno de emigrantes?. II Jornadis sobre Pohlación Española. Palma de Mallorca. Public. de la Universidad de la Islas Baleares, pp. 459-468.

A\%CARATE B. (1988), Consecuencias demográficas de la emigración y el retorno en Extremadura. Norba. 3. pp. 179-194.

CASTILLO J. (1997), "Teorías de la migración de retorno", in A. Izquierdo and (i. Alvarez (1997). Politica de retorno de emigrantes. La Coruña. Universidad Internacional de La Coruña. 300 p.

CAZORLA PÉREZ J. (1989), Remmo al Sur. Madtial. Siglo XXI. $249 \mathrm{p}$.

DELGADO G.. ASCANIO C. (1996). EI retorno reciente de los emigrantes canarios. 1986 a 1993. legula. 2. pp. 26.3-27.3
EISENSTADT N. S. (1973), Tradition, change and modernity, New York. Wiley.

EGEA JIMÉNEL C. $(2000)$, “Retorno y expectativas de retorno de los emigrantes andaluces jubilados. Aproximación al análisis de trayectoria de vida. in VVAA Sociedad, movilidad y muevos métodos en al estudio de la peblación española. AGE. Universidad de Huclva.

GARMENDIA J. A. (1981), La emigración expañola en la encracijada. Marco géneral de la e'migración de renorno, Madrid, CIS, $459 \mathrm{p}$.

GOMEZ J., BEL C. (1999), La corriente migratoria de retorno precedente de Europa a la Región de Murcia. Papele's de' (ieoegrafia, 30). pp. 67-85.

IEA (1993). Morilidad de la pohlación en Andalucia 1981-1990. Migracion internaciomal v corriente migraremia de remmen. Sevilla, vol. 3. $153 \mathrm{p}$.

LACOMBA J. (2001), "Teorías y prácticas de la inmigración. De los modelos explicativos a los relatos y proyectos migratorios". III Coloquio Internaional de Geocritica. Migración y Cambio Social. Barcelona. 
MALGESINI G. (1998). Cruzando fromteras. Migraciones' en el sistema mundial. Barcelona. Icaria.

MERCADÉ F. (1986), Metodología e historias de vida, Revista Internacional de Sociologia, Madrid. pp. 295319.

PASCUAL A. (1983), Los movimientos migratorios de retorno. Significación y perspectivas. Doituments d'Ancilisi Cieográfica, 3. pp. 47-69.

PASCUAL A. and Cardelús (1991-2). Migració des dones i historia personal. El retorn des d'Europa, Documents d'Anàlisi Googràfica, 1-20, pp. 81-102.

PASCUAL A. (1993). La migración de retorno en Europa: la construcción social de un mito. Polígonos. 3 , pp. 89-104.

PORTES A. BOROCZ J. (1998), "Migración contcmporánca: perspectivas teóricas sobre sus determinantes y sus modalidades de incorporación", in G. Malgesini. Cruzando fromteras. Migraciones en el sistema mundial. Barcelona. Icaria. pp. 43-7.3.

PUJADAS MUÑOZ J. J. (1992), El método biográfico: el uso de las historias de vida en las ciencias sociales.
Cuadernos metodológicos, 5. Madrid: Centro de Investigaciones Sociológicas.

PUJADAS I., GARCIA A. (1995). Migraciones Interiores en España. Tendencias recientes y perspectivas de futuro (1971-2000). Revista de (ieografia. 29(3). pp. $1-150$.

RAMÍREZ GOICOECHEA A. (1996). Immigramle's e'n España: vidas y experiencias. Madrid: Centro de Investigaciones Sociológicas. 610 p.

SANTAMARINA C., MARINAS J. M. (1994). "Historias de vida e historia oral". in J. M. Delgado y J. Gutiérrez (coord..), Métodos y té(micas cualitativas de imestigación en Ciencias Sociales. Madrid. Sintesis.

STARK O. (1991). The migration of labor. Cambridge. Basil Blackwell.

WALLERSTEIN I. (1974), The modern worid system. Capitalist agriculture and the origins of the european world economy in the sirte'mh century. New York. Academic Press. 1974.

WOOD C. (1992). Modelos opuestos en el estudio de la emigración, Alfoz. n"91-92. 